\title{
Exporting B2B Solutions: The Impact and Contribution of Using Social Media
}

\author{
By Ziad Abdelmoety*
Spiros Gounaris
}

Empirical insights on the effect of the use of social media, particularly for small and medium sized B2B firms for which such research is limited, could significantly improve on these firms' results. It is suggested that the implementation of social media will affect: the scope of their international contacts (Hamill et al. 2011), the awareness of these businesses (Weinberg 2009), the understanding of their customers' views (Constantinides et al. 2008), the understanding of their international competition (Governatori and Iannella 2011), and exporting performance (Rapp et al 2013). It is argued that global cultural differences will moderate the relationship between the implementation of social media and its internationalization effect, customer engagement will mediate the same relationship. This research contributes theoretically to the body of knowledge by developing a framework for evaluating the benefits of social media on the exporting efforts, which to the knowledge of the researcher has never been tested before. The moderator and mediating effects of some factors between the use of social media and its implications for exporting context has never been tested.

\section{Introduction}

Information Technology (IT) is important for organisations and this has been acknowledged since the late 1950's when articles, theorising about its impact, first began to appear (Leavitt \& Whisler, 1958). Nowadays, IT impacts on the value chain of the entire business, changes the whole structure of industries, leads to the establishment of new businesses, and enables all businesses to have the ability to create new competitive advantages (Nevo \& Wade, 2010).

Given its unique characteristics, especially its global reach and ease of use, researchers have noted that the Internet might constitute a powerful infrastructure which would enable businesses to develop their international processes, and, importantly, would be able to support and influence their

${ }^{*}$ PhD Student, University of Strathclyde, UK.

†Professor, University of Strathclyde, UK. 
growth (Hamill \& Gregory, 1997; Kotha et al. 2001; Lim et al. 2004; Vemuri \& Siddiqi, 2009; Culnan et al. 2010).

Since 1996, there has been an increasing amount of literature addressing the Internet's role in international business but, nevertheless, nearly all this research was based on what Levy termed "Web 1.0". This refers mainly to the first stage of the World Wide Web's development which, circa 2004, was superseded by what O'Reilly named "Web 2.0" (O'Reilly, 2005). Although, there is currently no formal and universally accepted definition of Web 2.0, it represented an important step change, in the technology which, compared to Web 1.0, offered businesses greater potential to develop their international operations.

The transition, from Web 1.0 to Web 2.0, represented a technological sea change from the "Internet as information repository" to becoming the "Internet as interactive platform" (Brock, 2001). Consequently, the introduction of interactive websites has allowed users to run applications on their browsers which enables them to own, edit and delete the website's contents items and, generally, to exercise control over its use. In addition, it enables websites to incorporate, through APIs (Application Programming Interface), other website' features. This is called the "mash-up" (Oren et al. 2007) and, most importantly, it empowers Internet users and enables them to use the Internet as a means of socialising. Web 2.0 empowered users to produce content themselves. As an alternative to their pulling information down from the Internet in a passive way, users began to actively generate their own information and to upload content onto newsgroups. These are either blogs referred to as collectively as blogospheres (Fieseler et al. 2010), or reference, review and community sites, like Wikipedia, or social sites such as LinkedIn or Facebook.

Often, although they may not be particularly knowledgeable about it, businesses believe that they have an obligation to become involved in social media. This is, simply, because they are aware that customers can be found there and that the majority of their competitors will have a presence already on social media. This desire to get involved in social media is reflected by businesses' increasing investment and usage of social media. An Altimeter (2013) survey concluded that companies plan to continue to increase spending on social media. Whilst the experts support strongly the advantages of social media platforms for marketing, businesses should not regard the decision, to use this new technology, as something which should be done automatically (Kaplan \& Haenlein, 2010).

Despite the popularity of social media networks, research into it is focused largely on B2C and there is scarcity of research on the B2B context. As Shih (2009) suggests, social media is very important for B2B companies.

Therefore, there is a need to understand the benefits and the outcomes to small and medium-sized exporting businesses of using social media platforms for B2B marketing purposes. This additional knowledge may help to provide businesses with appropriate guidance. In order better understand this domain, this research examines the effect of businesses using social media to support their B2B exporting efforts. To the best of the researcher's knowledge, there is 
a gap in the existing literature and, no one has previously undertaken such research. In order to fill this gap, this study will be conducted on small and medium sized business-to-business firms in the UK, providing empirical insights on the way social media affects these businesses.

Therefore, this study's objective is to explore how companies, in the business-to-business sector, could benefit potentially by adopting social media in their exporting efforts. Consequently, this study will examine how the implementation of social media affects: the scope of international contacts and networking (Hamill et al. 2011), the awareness of exporting businesses and their products (Weinberg, 2009; Immediate Future, 2008), the understanding of their customers' views (Kozinets, 2002; Constantinides et al. 2008), the understanding of their international competition (Dey et al. 2011; Governatori \& Iannella, 2011) and exporting performance (Rapp et al. 2013). It is argued that external factors such as cultural differences and customer engagement moderate and mediate the relationship between the implementation of social media and its effect on the internationalization of the businesses' activities.

\section{The Need for Social Media Among International Business to Business Firms}

\section{Theoretical Base - The Uppsala Model}

The internationalisation process of firms is essentially a learning process (Johanson and Vahlne, 1977; 2009).

The Uppsala internationalization process model as developed by Johanson and Vahlne (1977; 2009) is the most cited and influential model of internationalization (Eeden, 2009). In its most recent development, internationalization is seen as the outcome of firm actions to strengthen network positions internationally (Johanson and Vahlne, 2009).

Therefore, in order to internationalize successfully, firms need to be insiders in relevant business networks. This allows firms to become accustomed to internationalization process and potentially increase their influence within the network. As company activities and influence grow, the effect on customers and sales should also grow. So Uppsala provides the theoretical rationale for considering social media to be of high relevance.

Based on the work of Penrose (1966), Cyert \& March (1963), and Aharoni (1966), the original Uppsala model, contains two mechanisms to effect change. By applying the first mechanism, businesses effect change by learning from the experiences of their operations and activities in overseas markets. In applying the second mechanism, change is made through the business's decisions and commitments to reinforce their positions in the overseas market. Through its experiences, a business's knowledge of a market grows and that knowledge affects decisions concerning the level of commitment and activities which follow. This model is the most influential and cited model of internationalisation (Eden, 2009). 
The original Uppsala model assumed that the internationalisation process would continue until the performance and prospects ceased to be favourable. It assumed also that time was required to learn and build commitment. For this reason, moves, into potentially rewarding but hazardous modes, and moves, into markets involving a greater physical distance, were made incrementally.

According to several studies, there is clear evidence of the importance of networks in the internationalisation of businesses. This demonstrates the need to develop further the original Uppsala model to better understand the role of such networks (e.g. Coviello \& Munro, 1997; Welch \& Welch, 1996; Elango \& Pattnaik, 2007).

Similar to the 1977 version of the Uppsala model (Johanson \& Vahlne, 1977), the 2009 business network model (Johanson \& Vahlne, 2009) is comprised of two sets of variables; state variables and change variables. These variables influence each other since the current state has an effect on change and vice versa. The changes in the new (2009) model include the addition of "recognition of opportunities" to the "knowledge" concept. Opportunities represent a key subset of knowledge through which the networking process is driven. In their institutional settings, the needs, capabilities, strategies, and networks, of directly or indirectly related companies, comprise other important elements of knowledge. The second state variable is called "network position." Originally, this was labelled "market commitment"; however, nowadays, it is accepted that the internationalisation process is carried out within a network. The network's characteristics include particular levels of knowledge, trust, and commitment, although these may not be distributed evenly among those parties concerned with the process. Therefore, these relationships may vary in their promotion of successful internationalisation.

With regard to the change variables, the original label of "current activities" was changed to "learning, creating, and trust-building" in order to clarify the outcomes of current activities.

The rapidity, intensity, and effectiveness, of the processes of learning, creating knowledge, and establishing trust, depend on prior existence of knowledge, trust, commitment, and, above all, the extent to which the partners find these given opportunities attractive.

Finally, the other change variable, "relationship commitment decisions," was adapted from the original Uppsala model. "Relationship" was added to clarify that commitment was involved in relationships or networks of relationships. The implication, of this variable, is that the focal business can decide to either increase or decrease the level of commitment to one or more of the relationships in its network.

The theoretical model below, which will be explained in more depth by subsequent hypotheses and support, illustrates how the drivers of the Uppsala model can impact exporting outcomes through the use of social media. As social media efforts are expanded, contacts are made with more customers. If the social media efforts are effective, then other outcomes like brand awareness, customer knowledge, competition knowledge, customer engagement and exporting performance will also be positively affected. This 
will tend to greater exporter confidence in the opportunity and stronger commitments to further expand social media efforts.

\section{Social Media and the Number and Quality of Contacts}

In the social exchange process, weak links and unilateral dependence can be transformed into strong relationships and bilateral interdependence. As a consequence, these relationships increase joint productivity gradually (Zajac \& Olsen, 1993). In the marketplace, it was shown that forging such relational links is vital to business performance (Coviello \& Munro, 1997). Coviello et al. (1998) found that software managers perceived that competitive advantage emanated from the variety of their formal and informal contacts in key target markets. They also found that an association with unsuitable partners put a business at risk. Therefore, in order to internationalise successfully, businesses needed to be insiders in relevant business networks. Being on the inside allows businesses to learn, to build trust, and to commit to international business partners. These are the three core processes which make up the overall internationalisation process.

In light of a comparison between marketplace (physical market)and market space (virtual market) in terms of interactions, it was suggested that participation, in a communication setting such as those provided by market space, could extend the range and diversity of both weak and strong links (Lee et al. 2011). New types of media can facilitate and develop both types of links and can supply the company with more diverse information than that offered by close links. This argument echoes the early, Web 1.0- grounded work of Brock, who argued that the internet's market space resulted in companies being freed from the constraints of their local marketplace-based networks (Brock, 2000). It is this network perspective which provides the theoretical rationale for considering social media-enabled networks to be highly relevant.

A number of studies have used social networking theory to study, business in a B2B context (Pitt et al. 2006; McCarthy et al. 2007). Consequently, social media is likely to be a new sphere of influence and to provide networking opportunities for businesses since it provides an opportunity to extend a company's searching ability and enables contacts to access it through various platforms such as blogs, Twitter and so forth.

P1: Social media use for international marketing has a significantly positive impact on the number of business contacts.

Social media allows businesses to engage with their customers in interactive conversations. Moreover, social media can assist in building a quality network. Hamill et al. (2011) stated that, within the LinkedIn site, a company could use the customer mapping exercise to identify the principal customer groups of interest, build a customer database, and, then, sift through this network to find the top quality contacts. This illustrates the impact that social media can have on building quality contacts. Therefore, the researcher proposes the following proposition:

P2: Social media use for international marketing has a significantly positive impact on the quality of business contacts. 


\section{Social Media and Customer Engagement}

The emergence and rise of new social media channels in the recent years has enabled customers to increasingly participate in the new forms of customer/firm interaction processes. Discussion forums, chat rooms, email, bulletin boards, blogs and social networks are just some of the tools facilitating interactive customer experiences, which strengthen a firm's social capital and build deeper strategic relationships through online interactions (Ellonen et al. 2010), eventually fostering customer engagement with specific brands (Brodie et al. 2013). In the same vein, there is a growing recognition that social media applications are useful for engaging customers (Aquino, 2012; Cheung et al. 2011). Hollebeek (2011) recognizes the importance of customer engagement in the so called Web 2.0 applications, which are designed in a way that enables companies to aggregate the information from their user base in order to expand company content as well as value. The more an individual is involved with the community, the more likely it is that he or she will contribute to it. Moreover, individuals come to feel responsible for the community because of their exchanges with other members (Wind \& Rangaswamy, 2001).

P3: The use of social media leads to increased levels of customer engagement.

\section{Social Media and Understanding Customers' Views}

Companies use information in generating their products and services. In addition to the knowledge needed to produce them, a company needs to, also, understand to whom, at what price, where, when and how the products and services should be sold, in order to get the best possible profit (Vuori \& Väisänen, 2009). Social media may help users to establish their online identities, create a presence, develop relationships, manage their reputations, join groups, engage in conversation, and share content (Kietzmann et al. 2011). These channels open new opportunities for businesses to interact with customers and to study their needs and preferences (Kozinets, 2002). This is nothing new since, by monitoring the social media domain, marketers can collect ample and high quality intelligence by listening to their customers' voices, i.e., what people say online about the firm, its products and its competitors. Social media offers amazing possibilities to tap into these voices since people talk a lot online $(\mathrm{Hu}, 2011)$. It is especially important for businesses to listen to the online customers' voices in order to learn about their experiences in using the product or brand and to identify trends and potential markets for new products (Constantinides et al. 2008).

The customers' online voice can be "heard" in online blogs, forums, bulletin boards, online communities and social networks. As a consequence, when consumers find other customers' experiences, product reviews, and comments in forums, blogs or other social media, they consider such views to be credible (Elliott, 2002; Bates et al. 2006). In this regard, viral sharing of customer experiences, which is a common phenomenon of the social media space, can lead to a product's success or failure. In turn, customers' reactions can severely disrupt costly marketing actions. Nevertheless, if companies 
collect and analyze customers' views, expressed online, this can provide precious and high quality information at a fraction of the time and cost of traditional market research (Burke et al. 2001; Constantinides et al. 2008). Many corporations try not only to tap into their customers' voices in an active way but they also offer their customers the possibility of expressing their opinions and ideas about the company's products or services (Hudson et al. 2012; Merrill et al. 2011). Nokia is one of these businesses which has invited its customers to join its online "Developer Community" by providing them with discussion boards, wiki-based applications and blogs. In other words, companies provide ways via social media for customers to become more engaged. From these interactions, companies can learn more and more about their customers. According to Kumar et al. (2010), the value of customer engagement is comprised of four dimensions: customer purchasing behavior, customer referral behavior, customer influencer behavior, and finally, customer knowledge behavior via feedback provided to the firm. Thus, following the last of these four dimensions, customer engagement leads to greater knowledge of customers and their behaviors. Thus, social media, through greater customer engagement, is essential tool for better understanding customers. Therefore, the researcher proposes the following proposition:

P4: Customer engagement derived from social media use for international marketing has a significantly positive impact on understanding customers' views and preferences.

\section{Social Media and Understanding the Competition}

The widespread adoption of social media tools has generated a wealth of textual data which contains hidden knowledge that businesses can use to gain a competitive edge. In particular, marketers can explore the vast amount of social media data in order to detect and discover new knowledge, such as understanding their competitors' buying habits and how the industry is changing, in order to improve their competitive advantage (Dey et al. 2011; Governatori \& Iannella, 2011).

In addition, decision makers can use the findings to develop new products or services and make informed strategic and operational decisions. It is believed that competitive intelligence can help businesses realize their strengths and weaknesses, enhance their effectiveness, and improve their customers' satisfaction (Lau et al. 2005). Competitive intelligence is defined as the identification and understanding of competitor weaknesses which can lead to the enhancement of the business's effectiveness, and competitive advantage over their competitors' products or services (Dey et al. 2011). A successful business should have the ability to process all available information on their competitors (e.g. customers' views; competitors' product prices; reviews of services and products) in order to identify what has happened and to predict what will happen in the immediate future (La Valle et al. 2010). Social media can be a major part of business learning about their competitors. Therefore, the researcher proposes following proposition: 
P5: Customer engagement derived from social media use for international marketing has a significantly positive impact in understanding the competition in different markets.

\section{Social Media and Increased Brand Awareness}

In the process of building a community, the first step which companies are required to take towards fostering customer loyalty is raising customer awareness (Algesheimer et al. 2005; McAlexander et al. 2002; Muñiz \& O'Guinn, 2001). In terms of customers appraising one another about products, services and so forth, there is an obvious record of the online word-of-mouth comments which have taken place (Godes \& Mayzlin, 2009; Kozinets et al. 2010). It has already been established that communication between consumers is an influential means of transmitting information (Dellarocas, 2003). The emergence of social media platforms has facilitated consumer-to-consumer communication and has accelerated communication especially between consumers who do not know each other (Duan et al. 2008). In this context, Godes and Mayzlin (2009) demonstrated that social media platforms were a cost-effective and simple alternative to accessing and gathering communications between consumers. Additionally, work on conversations between consumers has demonstrated that such conversations led to important business outcomes. For example, high quality interactions in B2B brand communities foster positive brand awareness and loyalty (Bruhn et al. 2014).

From the customer's point of view, it is beneficial to use new media as a convenient way of making businesses aware of defects in their products. This helps the company to improve customer service, and, in particular, benefits the company and other customers through more rapid problem resolution (Shankar et al. 2003; Zeithaml et al. 2001). By monitoring customer-to-customer interactions, companies can also become aware of consumer dissatisfaction and unfavourable events. Consequently, they are able to take appropriate evasive action (Shankar et al. 2003; Zeithaml et al. 2001) and avoid disruption to business growth.

The other literature stream related to brand awareness concerns the influence of marketing communications on marketing outcomes. In a study, aimed at developing a model to measure brand equity, Simon and Sullivan (1993) identified marketing communications as one of the sources which drove brand awareness. In their study, Yoo et al. (2000) showed that marketing communications exerted a positive influence on perceived brand awareness. However, previous research, concerning the relationship between marketing communications and brand awareness, focused only on traditional marketing communication instruments (Aaker, 1991; Keller \& Lehmann, 2003; Yoo et al. 2000).

P6: The use of social media is positively related to brand awareness.

Consequently, when firms use new media to simply apprise customers of new products or services, this can be understood as traditional online marketing (Chatterjee et al. 2003; Stewart \& Pavlou, 2001). However, Weber (2009) argued that a strong brand ought to be based on the dialogue between a 
business and its customers. Social media allows companies to enter into these kinds of dialogues with customers. A key aspect of brand awareness is to target specific audiences across many different types of social media platforms (Weinberg, 2009). As users spend their time on various social media sites, companies should diffuse their presence across many kinds of social media but, at the same time, remain relevant to each community. A creative method of increasing brand awareness is to identify the individuals who influence the online communities relevant to a business. Through careful and deliberate decisions to convert these individuals into brand ambassadors, i.e. individuals who are very enthusiastic about a business's products or services, the business can indirectly access and influence potential audiences in relevant online communities (Safko \& Brake, 2009). This type of personalized attention to customers would likely lead to increased customer engagement and stronger awareness of the firm by customers. For example, Immediate Future's research (2008) showed that active participation, on social media sites, had a positive influence on a business's brand awareness. Brand awareness's importance is not seen necessarily in immediate sales but in consumers later remembering, a business's product or service and returning to it to make purchases (Weinberg, 2009).

The direct effect of social media and customer engagement on awareness is quite well established in other prior research. Bond (2010) concludes that brand awareness is an outcome of customer engagement in the social media context. This was supported by the results of the study by Shojaee \& Bin Azman (2013) indicating that customer engagement in the social media context is the strongest positive factor that affecting brand awareness (more than brand exposure and electronic-word-of-mouth. In the same vein, social media is considered as a way to expose customers to the brand and, the more consumers that engage with it, the higher the awareness of the brand (Hutter et al. 2013; Michaelidou et al. 2011). In addition, Bowden (2009) addresses the concept of engagement as the superior predictor of customer loyalty.

Therefore, the researcher proposes the following proposition:

P7: Customer engagement via social media use for international marketing has a significantly positive impact on brand awareness.

\section{Social Media and Export Performance}

Preliminary research indicates that social media is tied to outcome performance. Forty nine percent of sellers from the USA, UK, Brazil and China indicate that social media is important to their success (Fetherstonhaugh, 2010). From the same sample, among the most successful salespeople, over two-thirds believe social media is integral to their sales success. In the same vein, Business Wire (2012) illustrates that a number of SMEs out of 680 SMEs in UK report that social media has a rapid effect on the growth of sales in their enterprises. A survey of 668 New Zealand small and medium-size businesses found that New Zealand small businesses that use social media as part of their online business strategy are more likely to achieve bigger revenue returns from their platforms (Domainz eBiz Review, 2010). In a study of financial advisors, 
those who used social media noted a 19 percent increase in revenue during the previous year and expanded their client base by 21 percent. In a survey of 3000 marketers, more than half of them reported that it has helped hem improved sales. In addition, Rapp et al. (2013) concluded that social media use by B2B firms positively contributes to brand performance of the supplier (total store sales).

On the other hand, Rodriguez et al. (2012) concluded that social media usage by B2B firms has no relationship with outcome-based sales performance. Perhaps the reason for those null results was the importance of the effectiveness of social media, e.g. the engagement of customers with the social media efforts. In order to achieve goals in terms of metrics like profitability, market share, and revenue, customer needs must first be met; this can be done by engaging customers (Sashi, 2012). In the same vein, online brand communities, as a type of customer engagement, have been found to be effective tools for influencing sales. They have a direct positive impact on immediate purchase intention (Blazevic et al. 2013), and are effective tools for influencing sales, regardless of whether these communities reside on companyowned or independently-owned websites (Adjei et al. 2010). Thus engagement might be one of the keys to success for positive exporting outcomes using social media. So the following proposition can be displayed:

P8: Customer engagement from social media use for international marketing has a significantly positive impact on exporting performance.

\section{Moderating Effects of Culture}

Building global internet marketing strategy that overcomes cultural barriers is considered a critical factor in the success of marketing (Chan \& Swatman, 2010; Kotab \& Helsen, 2000). Several studies have been conducted with the aim of discovering whether localised or standardised websites are preferred by users (Faiola \& MacDorman, 2008; Cyr \& Trevor-Smith, 2004; Singh et al. 2005; Vyncke \& Brengman, 2010). The findings of these studies indicate that users tend to visit localised websites more often and to remain on them longer. In this light, Singh et al. (2005) conclude that cultural variations should be taken into account in website design and that websites should be localised.

Burson-Marsteller (2009) reports that two-thirds of Fortune Global 100 companies have Twitter accounts, over half have Facebook pages, half have YouTube video channels, and one-third have corporate blogs. UM Social Media Tracker Wave 5 (2010) conducted an international study of social media usage and found that almost $75 \%$ of Internet users had used online social networking sites. However, the extent of social media use is not necessarily consistent worldwide. Data on the use of social media indicates that there are considerable differences among countries regarding social media use (Goodrich \& DeMooij, 2013), the creation of content and the sharing of "crowd wisdom".

In social media diffusion, the significance of culture and language cannot be neglected, as social media are created "by the people, for the people" in an 
unprecedented online social context (King, 2010). One of the most widely-used social media platforms for international business is LinkedIn, where one approach to overcoming the language barrier has been to make provision for the formation of groups and sub-groups specifically for non-English-speaking users, to employ group managers who are multi-lingual (Bruno, 2011) and to allow the creation of personal profiles in several languages (Quattlebaum, 2012). Posts in various languages can be made to the group and content can also be translated, while multi-lingual podcasts and videos can also be presented in blogs to attract attention from members of different language communities. Quattlebaum (2012) suggests that blogs should be localised as well as simply translated and that firms should create Twitter accounts in a number of languages for different target markets, including hash tags that are understandable and related to these targets (Quattlebaum, 2012). While almost $70 \%$ of Facebook users are outside the United States and Facebook makes available 70 translations, businesses can also take advantage of overseas social media platforms such as WeiBao, Hyves or Orkut. Facebook is not the only social media platform investigating methods to expand and share multilingual content in real time through social media applications and crowd sourcing models.

Singh, Lehnert, \& Bostick (2012) argue that businesses wishing to enter international markets should translate and localise their social media platforms if they truly want to penetrate global markets. In this way marketing objectives such as increasing website traffic, raising brand awareness, generating leads, above all, increasing global revenues, can be accomplished. Based on this, it can be hypothesised that:

P9: Global culture differences moderate the relationship between the implementation of social media and its implications for exporting efforts. 


\section{The Model}

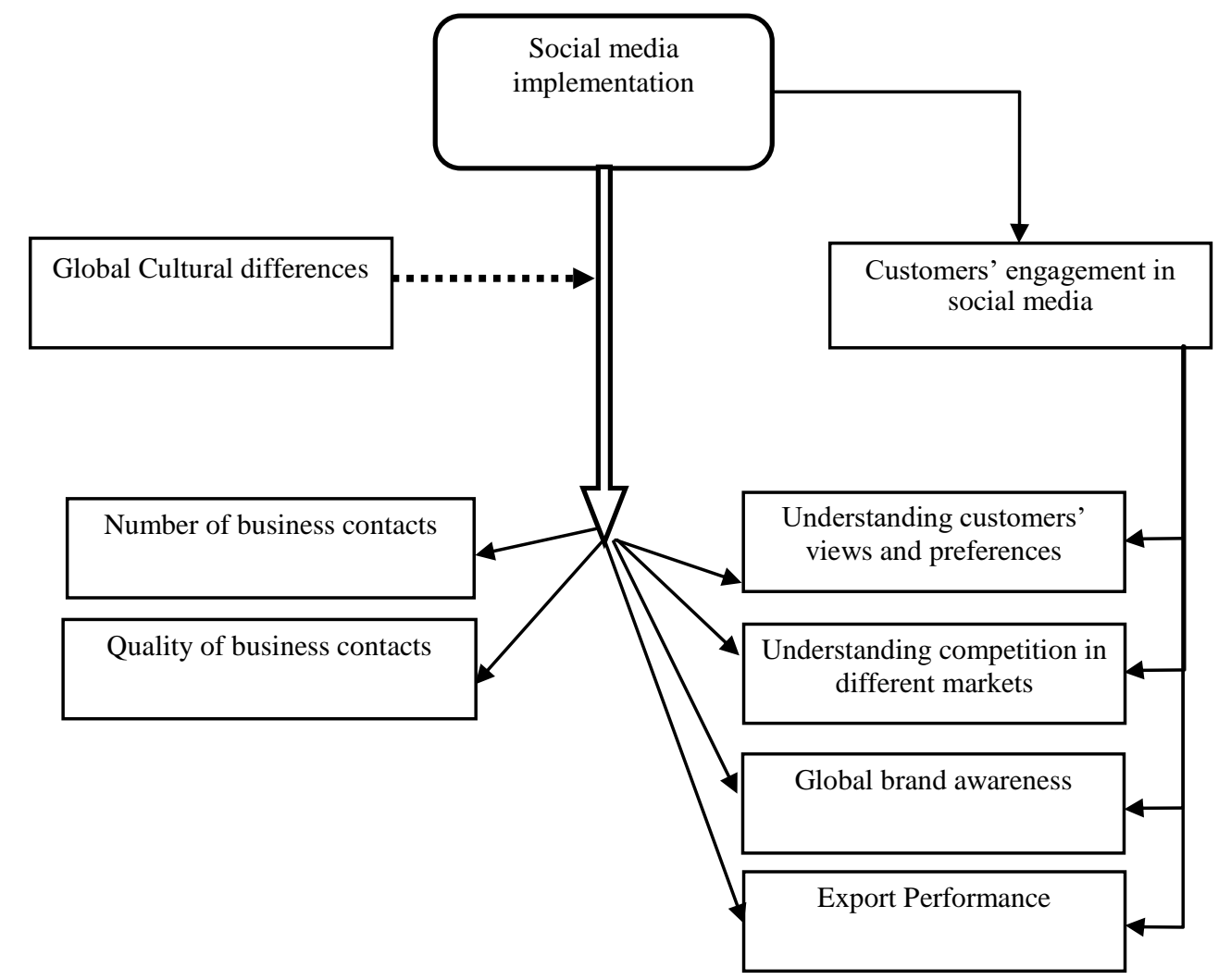

\section{Conclusion}

This study contributes theoretically to the existing knowledge by exploring the effect of using social media in a B2B context for businesses that export products and services. Consequently, it is suggested that the implementation of social media affects: the scope of businesses' international contacts and networking (Hamill et al. 2011), the awareness of these businesses and their products (Weinberg, 2009; Immediate Future, 2008), understanding customers' views (Kozinets, 2002; Constantinides et al. 2008), understanding the international competition (Dey et al. 2011; Governatori \& Iannella, 2011) and exporting performance (Rapp et al. 2013). It is argued that external environment factors moderate and mediate the relationship between the 
implementation of social media and its effect on businesses' internationalization. This research contributes theoretically to the body of knowledge linking social media marketing to research on exporting /internationalization by developing a framework to evaluate the benefits to business-to-business exporting small and medium sized firms of using social media in their efforts. To the best of the researcher's knowledge, this had never been tested before. Also, there has been no previous testing of the moderating effects of global cultural differences and the mediating effect of customer engagement on the successful exporting of products and services.

\section{References}

Aaker, D. A. (1991). Managing Brand Equity, NY: The Free Press.

Adjei, M. T., Noble, S. M, \& Noble, C. H. (2010). 'The influence of C2C communications in online brand communities on customer purchase behaviour'. Journal of the Academy of Marketing Science, 38(5): 634-653.

Aharoni, Y. (1966). The foreign investment decision process. Boston, MA: Harvard Business School Press.

Algesheimer, R., Dholakia, U. M, \& Herrmann, A. (2005). 'The Social Influence of Brand Community: from Evidence European Car Clubs'. Journal of Marketing, 69(3): 19-34.

Altimeter. (2013). The State of Social Business 2013: The Maturing of Social Media into Social Business. [Accessed 7 March 2014]. Available from: http://www.sli deshare.net/Altimeter/report-the-state-of-social-business-2013-the-maturing-of-so cial-media-into-social-business?ref=http://www.briansolis.com/2013/10/altimete r-groups-state-of-social-business-2013-report/.

Aquino, J. (2012). Find the right social media monitoring tool. Customer Relationship Management, 16(6), 33-37.

Bates, B., Romina, S., Ahmed, R., \& Hopson, D. (2006). 'The effect of source credibility on consumers' perceptions of the quality of health information on the Internet'. Medical Informatics and the Internet in Medicine, 31(1): 45-52.

Blazevic, V., Hammedi, W., Garnefeld, I., Rust, R. T., Keiningham, T., Andreassen, T.W., Donthu, N, \& Carl, W. (2013). 'Beyond traditional word-of-mouth: an expanded model of customer-driven influence'. Journal of Service Management, 24(3): 294-313.

Bond, C. (2010). Engagement with social media and outcomes for brands: A conceptual framework. ANZMAC Annual Conference, Christchurch, New Zealand.

Bowden, J. L-H. (2009). 'The Process of Customer Engagement: a Conceptual Framework'. Journal of Marketing Theory and Practice, 17(1): 63-74

Brock, J. K. (2001). Market space and the new mechanism of internationalisation: some preliminary insights. In Taggart, J. H., Berry, M, \&McDermott, M. (eds.), Multinationals in a New Era: International Strategy and Management, Palgrave, New York, 88-104.

Brock, J.K.U. (2000). Information and Communication Technology in the Small Firm", in: Enterprise and Small Business: Principles, Practice and Policy, ed.: S. Carter, D. Jones Evans. Harlow: Prentice Hall, 384-408. 
Brodie, R. J., Ilic, A., Juric, B, \& Hollebeek, L. (2013). 'Consumer engagement in a virtual brand community: An exploratory analysis'. Journal of Business Research, 66: 105-114.

Bruhn, M., Schnebelen, S, \& Schäfer, D. (2014). 'Antecedents and consequences of the quality of e-customer-to-customer interactions in B2B brand communities'. Industrial Marketing Management, 43: 164-176.

Bruno, M. (2011). Global view notes: Social Media Marketing for International Trade Shows, Rogers Worldwide, 1-2.

Burke, R. R., Rangaswamy, A., \& Gupta, S. (2001). Rethinking Market Research in the Digital World. In J. Wind \& V. Mahajan (Eds.), Digital Marketing. Global Strategies from the Worlds' Leading Experts, 226-255.

Burson-Marsteller. (2009). The global social media check-up study. [Accesses 15 Feb 2012]. Available from: www.bursoan-marsteller.com.

Business Wire. (2012). Four Out of Ten UK SMEs Adopt Social Media Marketing. Retrieved from http://www.businesswire.com/news/home/20120216005265/ en/Ten-UK-SMEs-Adopt-Social-Media-Marketing.

Chan, C, \& Swatman, P. M. C. (2010). EDI implementation: A broader perspective, 11th International Conference on Electronic Commerce, Bled, Slovenia.

Chatterjee, P., Hoffman, D. L, \& Novak, T. P. (2003). 'Modelling the Clickstream: Implications for Web-based Advertising Efforts'. Marketing Science, 22(4): 520541.

Cheung, C. M. K., Lee, M. K. O, \& Jin, X-L. (2011). Customer Engagement in an Online Social Platform: A Conceptual Model and Scale Development. Proceedings of the International Conference on Information Systems (ICIS), Shanghai, China.

Constantinides, E., Lorenzo Romero, C, \& Gomez Boria, M.A. (2008).' Social media: A new frontier for retailers?'. European Retail Research, 22(1): 1-28.

Coviello, N. E, \& Munro, H. (1997). 'Network relationships and the internationalisation process of small software firms'. International Business Review, 6(4): 361-386.

Coviello, N. E., Ghauri, P, N, \& Martin, K.A-M. (1998). 'International competitiveness: Empirical findings from SME service firms'. Journal of international marketing, 6(2): 8-27.

Culnan, M. J., McHugh, P. J, \& Zubillaga, J. I. (2010). 'How Large U.S. Companies Can Use Twitter and Other Social Media to Gain Business Value'. MIS Quarterly Executive, 9(4): 243-259.

Cyert, R.D., \& March, J.G. (1963). A behavioral theory of the firm. Englewood Cliffs, NJ: Prentice Hall.

Cyr, D, \& Trevor-Smith, H. (2004). 'Localization of Web design: An empirical comparison of German, Japanese, and United States Web site characteristics'. Journal of the American Society for Information Science and Technology, 55(13): 1199-1208.

Dellarocas, C. (2003). 'The digitization of word-of-mouth, promise and challenges of online feedback mechanisms'. Management Science, 49(10): 1407-24.

Dey L., Haque, S. M., Khurdiya, A, \& Shroff, G. (2011). Acquiring competitive intelligence from social media. In Proceedings of the 2011 joint workshop on multilingual OCR and analytics for noisy unstructured text data.

Domainz eBiz Review (2010). Succeeding Online. September: Domainz-a Melbourne IT Company.

Duan, W., Gu, B, \& Whinston, A. B. (2008). 'Do online reviews matter? An empirical investigation of panel data'. Decision Support Systems, 45(4): 1007-1116. 
Eden, L. (2009). 'The JIBS40/AIB50 anniversary Issue: Innovations in International Business Theory'. Journal of International Business Studies, 40(9): 1407-1410.

Elango, B, \& Pattnaik, C. (2007). 'Building capabilities for international operations through networks: A study of Indian firms'. Journal of International Business Studies, 38(4): 541-555.

Elliott, K. M. (2002), Understanding consumer-to-consumer influences on the Web. Doctoral Dissertation, Duke University.

Ellonen, H-K, Tarkiainen, A, \& Kuivalainen, O. (2010). 'The Effect of Website Usage and Virtual Community Participation on Brand Relationships'. International Journal of Internet Marketing and Advertising, 6(1): 85-105.

Faiola, A, \& MacDorman, K. F. (2008). 'The Influence of Holistic and Analytic Cognitive Styles on Online Information Design: Toward a communication theory of cultural cognitive design'. Information, Communication \& Society, 11(3): 348374.

Fetherstonhaugh, B. (2010). The Future of Selling. OgilvyOne Worldwide.

Fieseler, C., Fleck, M, \& Meckel, M. (2010). 'Corporate social responsibility in the blogosphere'. Journal of Business Ethics, 91: 599-614.

Godes, D, \& Mayzlin, D. (2009). 'Firm-Created Word-of-Mouth Communication: Evidence from a Field Test'. Marketing Science, 28(4): 721-739.

Goodrich, K, \& De Mooij, M. (2013). 'How 'social' are social media? A crosscultural comparison of online and offline purchase decision influences'. Journal of Marketing Communications, 20(1-2): 103-116.

Governatori, G, \& Iannella, R. (2011). 'A modeling and reasoning framework for social networks policies'. Enterprise Information Systems, 5(1): 145-167.

Hamill, J, \& Gregory, K. (1997). 'Internet Marketing in the Internationalisation of UKSMEs'. Journal of Marketing Management, 13: 9-28.

Hamill, J., Stevenson, A, \& Hamill, V. (2011). Creating the buzz: social media for sustained export growth. [Accessed 14 May 2012]. Available from: http:// www.slideshare.net/jimh7171/social-media-export-session-march-2011-v4-final.

Hollebeek, L. D. (2011). 'Demystifying customer brand engagement: Exploring the loyalty nexus'. Journal of Marketing Management, 27(7-8): 785-807.

Hu, X. (2011). Social Media Business Model Analysis - Case Tencent, Facebook, and Myspace. Master thesis, Aalto University, Finland.

Hudson, S., Roth, M. S, \& Madden, T. J. (2012). Customer Communications Management in the New Digital Era, working paper, Centre for Marketing Studies, Darla Moore School of Business University of South Carolina.

Hutter, K., Hautz, J., Dennhardt, S, \& Fuller, J. (2013). 'The impact of user interactions in social media on brand awareness and purchase intention: the case of MINI on Facebook'. Journal of Product \& Brand Management, 22(5/6): 342351 .

Immediate Future. (2008). The top brands in social media report. [Accessed 14 May 2012]. Available from: http://www.immediatefuture.co.uk/resources/the-top-bran ds-in-social-media-report-2008.

Johanson, J, \&Vahlne, J.-E. (1977). 'The internationalization process of the firm: a model of knowledge development and increasing foreign market commitments'. Journal of International Business Studies, 8: 23-32.

Johanson, J, \&Vahlne, J-E. (2009). 'The Uppsala internationalisation process model revisited: from liability of foreignness to liability of outsidership'. Journal of International Business Studies, 40(9): 1411-1431.

Kaplan, A. M, \& Haenlein, M. (2010). 'Users of the world, unite! The challenges and opportunities of Social Media'. Business Horizons, 53(1): 59-68. 
Keller, K. L, \& Lehmann, D. R. (2003). 'How do brands create value?'. Marketing Management, 12(3): 26-31.

Kietzmann, J. H., Hermkens, K., McCarthy, I. P., \& Silvestre, B. S. (2011). 'Social media? Get serious! Understanding the functional building blocks of social media'. Business Horizons, 54(3): 241-251.

King, C. (2010). Do you need Social media localization? [Accessed 12 Oct 2011]. Available from: http://cindyking.biz/localization-of-social-media/.

Kotab, M, \& Helsen, K. (2000). Global Marketing Management. New York: John Wiley and Sons Inc.

Kotha, S., Rindova, V. P, \& Rothaerme, F. T. (2001). 'Assets and Actions: FirmsSpecific Factors in the Internationalisation of U.S. Internet Firms'. Journal of International Business Studies, 32(4): 769-791.

Kozinets, R. V. (2002). 'The Field Behind the Screen: Using Netnography for Marketing Research in Online Communities'. Journal of Marketing Research, 39: 61-72.

Kozinets, R. V., de Valck, K., Wojnicki, A. C, \& Wilner, S. J. S. (2010). 'Networked Narratives: Understanding Word-of-Mouth Marketing in Online Communities'. Journal of Marketing, 74(2): 71-89.

Kumar, V., Aksoy, L., Donkers, B., Venkatesan, R., Wiesel, T, \&Tillmanns, S. (2010). 'Undervalued or overvalued customers: Capturing total customer engagement value'. Journal of Service Research, 13(3): 297-310.

Lau, K., Lee, K, \& Ho, Y. (2005). 'Text mining for the Hotel Industry'. Cornell Hotel and Restaurant Administration Quarterly, 46(3): 344-362.

LaValle, S., Hopkins, M., Lesser, E., Shockley, R, \& Kruschwitz, N. (2010). 'Analytics: The new path to value'. MIT Sloan Management Review, 52(1): 1-25.

Leavitt, H.J. \& Whisler, T.L. (1958). Management in the 1980's. Harvard Business Review, November.

Lee, K-W., Tsai, M-T, \& Lanting, M. C. (2011). 'From marketplace to market space: Investigating the consumer switch to online banking'. Electronic Commerce Research and Applications, 10(1): 115-125.

Lim, K. H., Leung, K., Sia, C. L, \& Lee, M. K. (2004). 'Is eCommerce boundary-less? Effects of individualism-collectivism and uncertainty avoidance on Internet shopping'. Journal of International Business Studies, 35(5): 583-598.

McAlexander, J. H., Schouten, J. W, \& Koenig, H. F. (2002). 'Building Brand Community'. Journal of Marketing, 66(1): 38-54.

McCarthy, I., Pitt, L., Campbell, C., van der Merwe, R., \& Salehi-Sangeri, E. (2007). 'Exploiting the business opportunities in biotech connections: The power of social networks'. Journal of commercial biotechnology, 13(4): 245-257.

Merrill, T., Latham, K., Santalesa, R, \& Navetta, D. (2011). Social Media: The Business Benefits May Be Enormous, But Can the Risks -- Reputational, Legal, Operational -- Be Mitigated. [Accesses 11 May 2013]. Available from: http:// www.linkedin.com/lite/externalredirect?url=http\%3A\%2F\%2Fwww\%2Eacegro up $\% 2$ Ecom\%2Fus-en\%2Fassets\%2Face-progress-report-social-media\%2Epdf \&urlHash=T9EE.

Michaelidou, N., Siamagka, N. T, \& Christodoulides, G. (2011). 'Usage, barriers and measurement of social media marketing: An exploratory investigation of small and medium B2B brands'. Industrial Marketing Management, 40(7): 1153-1159.

Muniz, Jr, A.M, \& O'Guinn, T. C. (2001). 'Brand community'. Journal of Consumer Research, 27(4): 412-432. 
Nevo, S, \& Wade, M. R. (2010). 'The Formation and Value of IT-Enabled Resources: Antecedents and Consequences of Synergistic Relationships'. MIS Quarterly, 34(1) :163-183.

O'Reilly, T. (2005). Web 2.0: Compact Definition? Blog entry at O'Reilly Radar. [Accessed 16 July 2011]. Available from: http://radar.oreilly.com/archives/2005/ 10/Web_20_compact_definition.htm.

Oren, E., Haller, A., Mesnage, C., Hauswirth, M., Heitmann, B., \& Decker, S. (2007). A flexible integration framework for semantic Web 2.0 applications. IEEE Softw, 24(5): 64-71.

Penrose, E.T. (1966). The theory of the growth of the firm. Oxford: Basil Blackwell.

Pitt, L., van der Merwe, R., Berthon, P.R., Salehi-Sangari, E., \& Caruana, A. (2006). 'Global alliance networks: a comparison of biotech SMEs in Sweden and Australia'. Industrial Marketing Management, 35(5): 600-610.

Quattlebaum, K. (2012). ExportGA 2011: Social Media's Role in the Global Marketplace [Accessed 14 May 2012]. Available From: http://www.slidesha re.net/kellyquattlebaum/exportga-social-media-worldwide-global-marcoms.

Rapp, A., Beitelspacher, L.S., Grewal, D., Hughes, D.E. (2013). Understanding Social Media Effects Across Seller, Retailer, and Consumer Interactions. Journal of the Academy of Marketing Science, 41(5): 547-566.

Rodriguez, M., Peterson, R.M. \& Krishnan, V. (2012). Social Media's Influence on Business-to-Business Sales Performance. Journal of Personal Selling and Sales Management, 32(3): 365-378.

Safko, L, \& Brake, D. K. (2009). The social media bible: Tactics, tools and strategies for business success, Hoboken, NJ: John Wiley \& Sons.

Sashi, C.M. (2012). Customer engagement, buyer-seller relationships, and social media. Management Decision, 50(2), 253-272.

Shankar, V., Smith, A. K, \& Rangaswamy, A. (2003). 'Customer Satisfaction and Loyalty in Online and Offline Environments'. International Journal of Research in Marketing, 20(2): 153-175.

Shih, C. (2009). The Facebook Era: Tapping Online Social Networks to Build Better Products, Reach New Audiences, and Sell More Stuff, Boston: Prentice Hall.

Shojaee, S, \& Bin Azman, A. (2013). 'An Evaluation of Factors Affecting Brand Awareness in the Context of Social Media in Malaysia'. Asian Social Science, 9(17): $72-78$

Simon, C. J, \& Sullivan, M.W. (1993). 'The measurement and determinants of brand equity: a financial approach'. Marketing Science, 12(1): 28-52.

Singh, N., Lehnert, K, \& Bostick, K. (2012). 'Global Social Media Usage: Insights Into Reaching Consumers Worldwide'. Thunderbird International Business Review, 54(5): 683-700.

Singh, N., Zhao, H, \& Hu, X. (2005). 'Analyzing the cultural content of web sites: A cross-national comparision of China, India, Japan, and US'. International Marketing Review, 22(2): 129-146.

Stewart, D. W, \& Pavlou, P. A. (2001). 'From Consumer Response to Active Consumer: Measuring the Effectiveness of Interactive Media'. Journal of the Academy of Marketing Science, 30(4): 376-396.

Vemuri, V. K, \& Siddiqi, S. (2009). 'Impact of Commercialization of the Internet on International Trade: A Panel Study Using the Extended Gravity Model'. International Trade Journal, 23(4): 458-484.

Vuori, V, \& Väisänen, J. (2009). The use of social media in gathering and sharing competitive intelligence, The 9th International Conference on Electronic Business, Macau. 
Vyncke, F, \& Brengman, M. (2010). 'Are Culturally Congruent Websites More Effective? An Overview of a Decade of Empirical Evidence'. Journal of Electronic Commerce Research, 11(1): 14-29.

Weber, L. (2009). Marketing to the social web, NJ: John Wiley \& Sons.

Weinberg, T. (2009). The new community rules: Marketing on the social web, Sebastopol, CA: O'Reilly Media, Inc.

Welch, D. E, \& Welch, L. S. (1996). 'The internationalisation process and networks: A strategic management perspective'. Journal of International Marketing, 4(3): 11-28.

Wind, J, \& Rangaswamy, A. (2001). 'Customerization: The next revolution in mass customization'. Journal of Interactive Marketing, 15(1):13-32.

Yoo, B., Donthu, N, \& Lee, S. (2000). 'An examination of selected marketing mix elements and brand equity'. Journal of the Academy of Marketing Science, 28(2):195-211.

Zajac, E. J, \& Olsen, C. P. (1993). 'From transaction cost to transactional value analysis: Implications for the study of organisational strategies'. Journal of Management Studies, 39(1):131-145.

Zeithaml, V. A., Parasuraman, A, \& Malhotra, A. (2001). 'Service Quality Delivery Through Web Sites: A Critical Review of Extant Knowledge'. Journal of the Academy of Marketing Science, 30(4): 362-375. 